\title{
QUANTITATIVE AND QUALITATIVE ANALYSIS OF AgNOR IN BENIGN AND MALIGNANT CANINE MAMMARY GLAND TUMORS
}

\author{
JELESIJEVIĆ T, JOVANOVIĆ M, KNEŽEVIĆ MILIJANA and ALEKSIĆ-KOVAČEVIĆ SANJA \\ Faculty of Veterinary Medicine, Belgrade \\ (Received 11. July 2003)
}

In this retrospective study, quantitative and qualitative analyses of argyrophil nucleolar organizer regions (AgNORs) in 54 malignant and 18 benign canine mammary gland tumors were made. Statistical analysis showed a significant difference in the mean number of AgNORs per cell between benign and malignant tumors $(p<0.01)$. There was no significant difference in the mean number of AgNORs per cell between complex carcinomas, simple carcinomas and carcinomas in mixed tumors ( $p>0.05)$, as well as between adenomas and benign mixed tumors ( $p>0.05)$. Six different patterns of AgNOR distribution were observed. Types I, II, III and in only two cases, type IV, were observed in benign tumors, while all six types were observed in malignant tumors. The predominant types in malignant tumors were III, IV, V and VI. Cell types II, III and IV were predominant in malignant tumors with 5.5-7 AgNORs per cell, while cell types $V$ and VI were dominant in tumors with more than 7 AgNORs per cell.

Key words: dog, mammary gland, tumors, AgNOR

\section{INTRODUCTION}

During the last several years canine mammary gland tumors have raised great interest both in human and veterinary pathology. Due to their short life span, the relatively rapid progression of the disease and a large number of potential foci (ten mammary glands), dogs are becoming an ideal animal model for studying breast tumors in women (Hellmen, 1996; Magaš, 2002).

Thus, the frequency of canine mammary gland tumors immediately follows skin tumors, being at the same time the most common neoplasm in bitches. According to the reports of the majority of authors, these tumors comprise about 25$50 \%$ of all canine tumors with an approximately equal malignant and benign neoplasm incidence (Cotchin, 1958; Bostock, 1986; Moulton, 1990; Benjamin et al., 1999). Carcinomas comprise about $80-90 \%$ of all malignant mammary gland tumors (Fidler and Brodey, 1967; Moulton et al., 1970; Moulton et al., 1986), sarcomas $5-10 \%$, while carcinosarcomas are rare malignant mammary gland tumors (Misdorp et al., 1971; Benjamin et al., 1999). Regarding the frequency of different benign mammary gland tumors, adenoma is the most common benign neoplasm 
comprising more than $60 \%$ of all benign neoplasms, followed by benign mixed tumors (30\%) and duct papillomas (10\%) (Benjamin et al., 1999).

The exceptionally diverse histological appearance and the presence of a continuum between benign and malignant tumors, as well as ambiguities related to tumor cell origin and the roles of different growth factors and hormones represent major problems for correct interpretation of canine mammary gland tumors. Due to these extremely complex problems none of the existing histological classifications can entirely fulfil the needs of pathologists, clinicians and pet owners (Jelesijević, 2001). Therefore, great efforts are being made to identify a standard histological classification of mammary gland tumors as well as reliable diagnostic and prognostic methods (Hampe and Misdorp, 1974; Bostock et al., 1992; Hellmén, 1996; Benjamin et al., 1999; Misdorp et al., 1999)

Staining of nucleolar organizer regions (NORs) with silver colloid is indicated in the literature as a highly reliable histochemical prognostic method (Giri et al., 1989; Kiupel et al. 1998). NORs represent chromosomal parts rich in rDNA that participate in the formation of a nucleolus (Goessens, 1984). Actively transcribing NORs are argyrophil (AgNORs) and can be visualised by applying silver colloid. Eight autosomes Nos. 5, 8, 14, 16, 19, 21, 32, 37 and the Y chromosome showed active NORs in dogs (Howard-Peebles and Howell, 1983; Shibasaki et al., 1990).

Numerous studies on different neoplasms in animals and humans indicated that a lower average AgNOR count and higher diameter of AgNORs are associated with a more favourable prognosis and longer survival time (Crocker and Nar, 1987; Crocker and Egan, 1988; Bostock et al., 1989; Bostock et al., 1992; Kravis et al., 1996; Chu et al., 2001). Investigation of canine T and B malignant lymphomas showed that the dogs with tumors with a lower average AgNOR count, a higher maximal as well as average AgNOR area, a lower AgNOR - nucleus ratio and a shorter average distance between two AgNORs had a more favourable prognosis (Kiupel et al., 1998; Kiupel et al., 1999).

Several proposals have been made in order to standardize the AgNOR counting technique (Crocker et al., 1989; Rüschoff et al., 1994; Aubele et al., 1994). Although, the technique has been standardized, this still represents a weak point of the method. Unfortunately, not only the counting technique but also "external" factors such as; fixation time (Biesterfeld et al., 1994), thickness of the sections, temperature, pre-treatment procedures and staining time, have a great influence on AgNOR count (Kiupel et al., 1999). Therefore, the prognostic value of the distribution of AgNORs is still being investigated. This parameter is less susceptible to subjective estimation than an individual count of AgNORs, which should help in the comparison of results between different studies (Kiupel et al., 1998). Recently, an image analysis technique for interpretation of AgNORs has been favoured by some authors (Kiupel et al., 1998; Juntes and Pogačnik 2000), whereas others consider direct counting more accurate (Bostock et al., 1992; Bratulić et al., 1996). As every histopathological section has a specific thickness, more reliable data concerning AgNOR counts can be obtained by focusing on each AgNOR that is not in the same plane as the other AgNORs within the same nucleolus (Bratulić et al., 1996). Such accurate counting of each AgNOR is not possible to achieve by image analysis software. Also, due to its price, image analysis software 
Jelesijević T et al. Quantitative and qualitative analysis of AgNOR in benign and

malignant canine mammary gland tumors

is not affordable for every institution, which probably represents the main disadvantage.

\section{MATERIAL AND METHODS}

Seventy-four tissue samples of canine mammary gland tumors were examined in this study. The tumors were classified according to the WHO classification (Misdorp et al., 1999). The samples were fixed in 10\% neutral buffered formalin and embedded in paraffin. Following the usual rehydration procedure, silver colloid staining was performed on $3 \mu \mathrm{m}$ thick sections. The working solution was composed of two volumes of $33 \% \mathrm{AgNO}_{3}(\mathrm{aq})$ and one volume of $2 \%$ gelatine in $1 \%$ formic acid, was added and the sections kept in a dark chamber at $25^{\circ} \mathrm{C}$ for 40

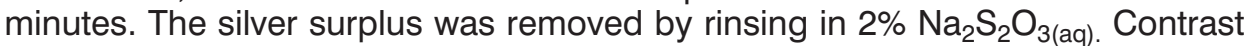
staining was performed using nuclear fast red, neutral red and hematoxylin. AgNORs were counted under oil immersion, and each clearly demarcated AgNOR was considered as a unit structure.

Statistical analysis included Student's t-test and analysis of variance. The obtained data were described using the following statistical parameters: arithmetic mean $(X)$, standard deviation (SD), standard error (Sy) and interval of variation (Iv).

\section{RESULTS}

After analysis of tumors stained with silver colloid the average number of AgNORs was calculated per cell. Malignant tumors had an average of 7.18 AgNORs while benign tumors had 3.53 AgNORs/cell (Table 1).

Table 1. AgNOR count, for malignant and benign mammary gland tumors

\begin{tabular}{||l|c|c|c|c|c||}
\hline \multicolumn{1}{|c|}{ Type of tumor } & $\begin{array}{c}\text { Number of } \\
\text { samples }\end{array}$ & $\mathrm{X}$ & $\mathrm{SD}$ & Sy & IV \\
\hline \hline Malignant tumors & 54 & 7.18 & 1.12 & 0.30 & $5.75-9.88$ \\
\hline Benign tumors & 18 & 3.52 & 0.77 & 0.18 & $1.91-5.05$ \\
\hline
\end{tabular}

Student's t-test showed a statistically significant difference in the average number of AgNORs/cell between malignant and benign canine mammary gland tumors $(p<0.01)$.

In cases of adenomas (Figure 1) and benign mixed tumors, an average of 3.37 and 3.81 AgNORs/cell were counted, respectively. Duct papillomas had an average number of $3.41 \mathrm{AgNORs/cell,} \mathrm{but,} \mathrm{due} \mathrm{to} \mathrm{the} \mathrm{relatively} \mathrm{low} \mathrm{number} \mathrm{of} \mathrm{this}$ type of benign neoplasm, they were not included in the statistical analysis inside the group of benign neoplasms (Table 2). 


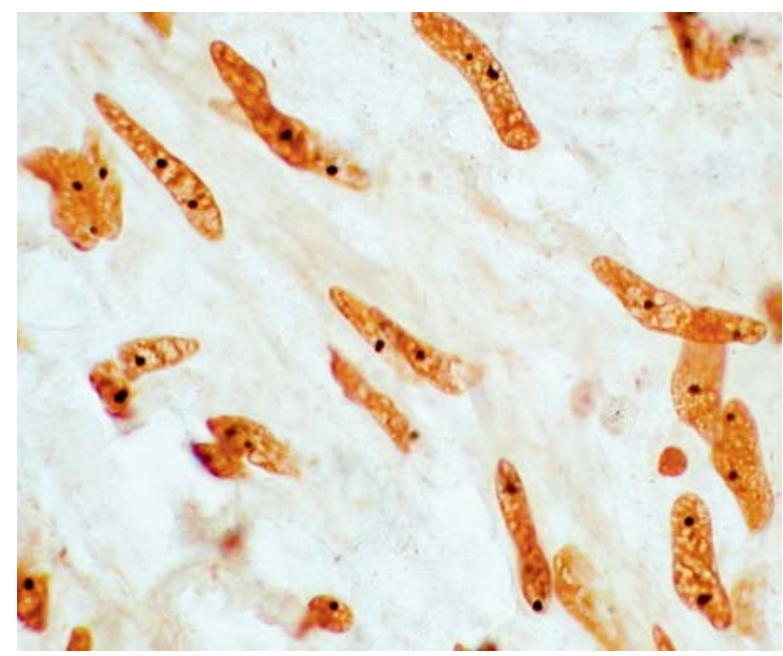

Figure1. Adenoma, myoepithelial type (x1000, silver colloid)

Table 2. AgNOR count within the group of benign mammary gland tumors

\begin{tabular}{|l|c|c|c|c|c||}
\hline \hline $\begin{array}{c}\text { Histological type of } \\
\text { benign neoplasm }\end{array}$ & $\begin{array}{c}\text { Number of } \\
\text { samples }\end{array}$ & $\mathrm{X}$ & $\mathrm{SD}$ & Sy & IV \\
\hline \hline Adenoma & 9 & 3,37 & 0,94 & 0,31 & $1,91-5,05$ \\
\hline Benign mixed tumor & 6 & 3,81 & 0,61 & 0,25 & $2,86-4,71$ \\
\hline Duct papilloma & 3 & 3,41 & - & - & - \\
\hline
\end{tabular}

Student's t-test did not show a statistically significant difference in average number of AgNORs/cell between adenomas and benign mixed tumors ( $p>0.05)$.

Average numbers of AgNORs/cell within the group of malignant tumors were: 7.29 for simple carcinomas (Figure 2), 7.12 for complex carcinomas and 7.04 for carcinoma in mixed tumors (Table 3 ).

Table 3. AgNOR count within the group of malignant mammary gland tumors

\begin{tabular}{||l|c|c|c|c|c||}
\hline $\begin{array}{c}\text { Histological type of } \\
\text { malignant neoplasm }\end{array}$ & $\begin{array}{c}\text { Number of } \\
\text { samples }\end{array}$ & $\mathrm{X}$ & $\mathrm{SD}$ & Sy & IV \\
\hline \hline Simple carcinoma & 23 & 7.29 & 1.11 & 0.22 & $5.80-9.82$ \\
\hline Complex carcinoma & 20 & 7.12 & 0.98 & 0.42 & $5.85-9.32$ \\
\hline Carcinoma in mixed tumor & 11 & 7.04 & 1.38 & 0.23 & $5.75-9.88$ \\
\hline
\end{tabular}

Analysis of variance did not show a statistically significant difference in average number of AgNORs/cell between any of the three types of malignant tumors $(p>0.05)$. 
Jelesijević T et al. Quantitative and qualitative analysis of AgNOR in benign and malignant canine mammary gland tumors

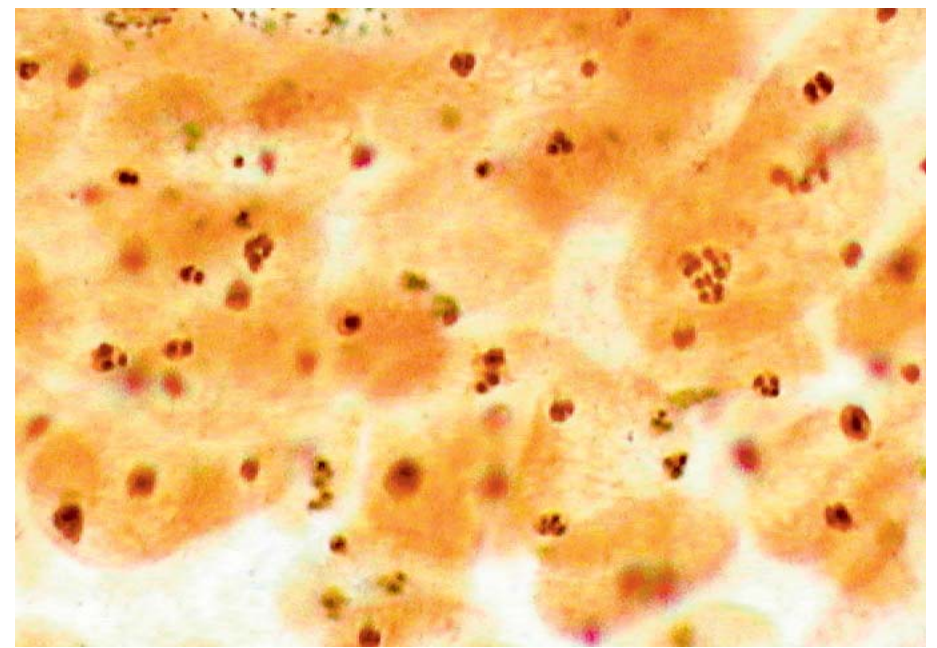

Figure 2. Simple carcinoma (x1000, silver colloid)

Based on the type of AgNOR pattern distribution, all the cells in the studied material were classified into six types. A certain number of cells showed the presence of two or even three different AgNOR patterns at the same time. Type I is characterized by the presence of one either centrally or peripherally located relatively large nucleolus with a large black coloured AgNOR in it (Figure3/I). In type II cells, 3-6 moderately sized round-shaped AgNOR structures were observed (Figure 3/II). In type III cells, the nucleoli usually contained 3-7 dot like AgNORs, while

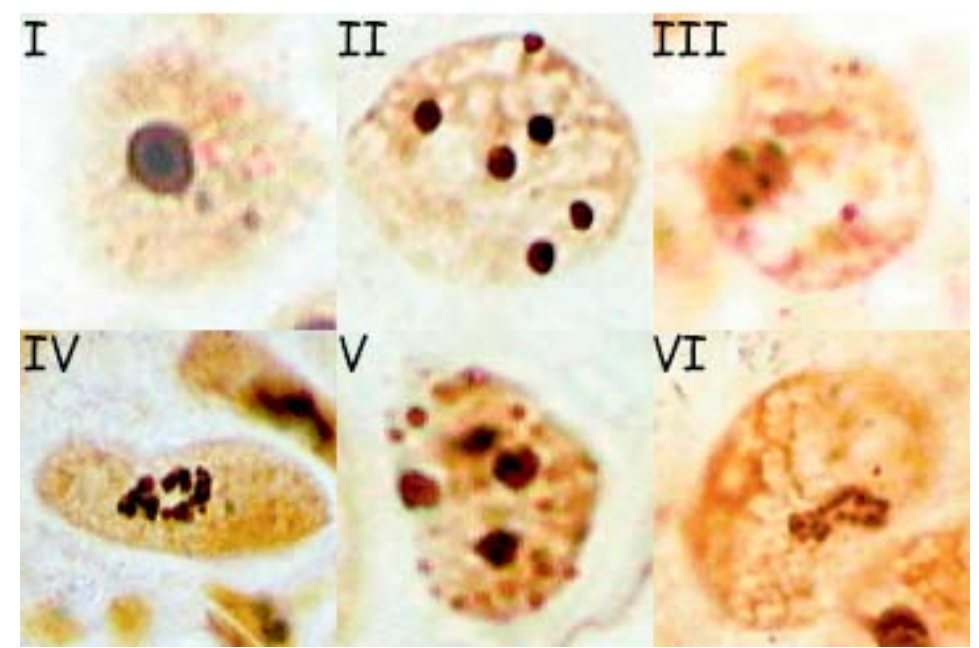

Figure 3. AgNOR pattern distribution 
in the rest of the nucleoplasm AgNORs like those in cells of type II and V could be observed (Figure 3/III). Type IV cells were characterized by the presence of an irregularly shaped nucleolus, containing several (3-6) aggregated/clustered AgNORs, while in the rest of the nucleoplasm AgNORs like those in cells of type II and $\mathrm{V}$ were frequently observed (Figure 3/IV). Type $\mathrm{V}$ cells were distinguished by 5-20 diffusely distributed dot like AgNORs (Figure 3/V). Type VI cells were characterized by a relatively large, elongated, sickle- or irregularly shaped nucleolus containing up to 20 dot like non-clustered/aggregated AgNORs (Figure 3/VI).

Cell types I, II, III and in only two cases cell type IV were observed in benign tumors. Although cell types I and II were also observed in malignant tumors, cell types III, IV, V and VI were the predominant cell population. Cells types II, III and IV were predominant in malignant tumors with 5.5-7 AgNORs per cell, while cell types $\mathrm{V}$ and $\mathrm{VI}$ were dominant in tumors with more than 7 AgNORs per cell.

\section{DISCUSSION}

Statistical studies suggest that canine malignant mammary tumors can be classified in order of increasing malignancy. Non-infiltrating carcinomas are at the very beginning, followed by complex carcinomas and simple carcinomas. Simple carcinomas have an increasing malignancy scale of their own - tubulopapillary carcinomas, solid carcinomas and anaplastic carcinomas, but the most malignant tumors of the canine mammary gland are sarcomas (Misdorp et al., 1999; Benjamin et al., 1999). As the average number of AgNORs/cell indicates the malignancy grade it could be expected that simple carcinomas have a higher AgNOR count than complex carcinomas or carcinomas in mixed tumors. Average AgNOR counts among carcinomas in this study were higher in simple carcinomas than in complex carcinomas they had a higher average AgNOR count per cell than did carcinomas in mixed tumors. However, the differences were not shown to be statistically significant. These results are similar to other studies regarding average AgNOR count and canine mammary gland tumors (Bostock et al., 1992; Harari et al., 1995; Bratulić et al., 1996; Juntes and Pogačnik, 2000). No significant difference between adenomas and benign mixed tumors were observed on comparing the same parameter by Student's t-test.

In one study on canine malignant lymphomas a significant correlation between AgNOR distribution and prognosis was observed (Kiupel et al., 1998). The AgNOR pattern distribution described in the mentioned study was considered in our work on AgNOR pattern distribution in the examined canine mammary gland tumors. Based on subjective estimation an inverse correlation between AgNOR count and size of AgNORs was noted.

According to the results of our study, it can be concluded that the presence of cell types $\mathrm{V}$ and $\mathrm{VI}$ is strongly suggestive of a malignant tumor of the canine mammary gland.

This study showed that besides the average AgNOR count, AgNOR pattern distribution could be a reliable parameter of malignancy. As the latter parameter is less susceptible to subjective estimation than the average AgNOR count, it is possible to compare results between different studies. Further investigations are nec- 
essary to establish a possible correlation between AgNOR pattern and survival time of bitches with mammary gland tumors.

Address for correspondence:

Tomislav Jelesijević

Faculty of Veterinary Medicine

Department of Pathology

Bul JNA 18

11000 Belgrade, Serbia \& Montenegro

\section{REFERENCES}

1. Aubele M, Biesterfeld S, Derenzini M, Hufnagl P, Martin M, Öfner D, Ploton D, Rüschoff J, 1994, Guidelines of AgNOR quantitation, Zentralbl Pathol, 140, 107-8.

2. Benjamin SA, Lee AC, Saunders WJ, 1999, Classification and behavior of canine mammary epithelial neoplasms based on life-span observations in beagles, Vet Pathol, 36, 423-36.

3. Biesterfeld S, Ruoss E, Hufnagl P, Martin H, 1994, Influence of fixation and preparation on the AgNOR distribution in routinely processed breast cancer specimens, Zentralb/ Pathol, 140, 41-8.

4. Bostock $D E, 1986$, Canine and feline mammary tumors, Br Vet J, 142, 506-15.

5. Bostock DE, Crocker J, Harris K, Smith P, 1989, Nucleolar organiser regions as indicators of postsurgical prognosis in canine spontaneous mast cell tumours, Br J Cancer, 59, 915-8.

6. Bostock DE, Moriarty J, Crocker J, 1992, Correlation between histologic diagnosis mean nucleolar organizer region count and prognosis in canine mammary tumors, Vet Pathol, 29, 381-5.

7. Bratulić M, Grabarević Ž, Artuković B, Capak D, 1996, Number of nucleoli and nucleolar organizer regions per nucleus and nucleolus-prognostic value in canine mammary tumors, Vet Pathol, 33, 527-32.

8. Chu RM, Lin CY, Liu CC, Yang SY, Hsiao YW, Hung SW, Pao HN, Liao KW, 2001, Proliferation characteristics of canine transmissible venereal tumor Anticancer Res, 21, 4017-24.

9. Cotchin E, 1958, Mammary neoplasms in the bitch, J Comp Path, 68, 1-22.

10. Crocker J, Paramijt N, 1987, Nucleolar organizer regions in lymphomas, J Pathol, 151, 111-8.

11. Crocker J, Egan MJ, 1988, Correlation between NOR sizes and numbers in non-Hodgkin's lymphomas, J Pathol, 156, 233-9.

12. Crocker J, Boldy DAR, Egan MJ, 1989, How should we count AgNORs? Proposals for a standardised approach, $J$ Pathol, 158, 185-8.

13. Fidler IJ, Brodey RS, 1967, The biological behavior of canine mammary neoplasms, JAVMA, 151, 1311-8.

14. Giri DD, Nottingham JF, Lawry J, Dundas SAC, Underwood JCE, 1989, Silver-binding nucleolar organizer regions (AgNORs) in benign and malignant breast lesions: correlations with ploidy and growth phase by DNA flow cytometry, J Pathol, 157, 307-13.

15. Goessens G, 1984, Nucleolar structure, Int Rev Cytol, 87, 107-56.

16. Hampe JF, Misdorp W, 1974, Tumors and dysplasias of the mammary gland, Bull WHO, 50, 111-33.

17. Harari R, Shahar R, Zuckerman A, Nyska A, 1995, Silver stained nucleolar organizer regions (AgNORs) in canine mammary tumors measured by image analysis and direct counting: correlation to histology and clinical behavior, Isr J Vet Med, 50, 147-56.

18. Hellmen E, 1996, The pathogenesis of canine mammary tumors, Cancer J, 9, 282-6.

19. Howard-Peebles PN, Howell WM, 1983, Nucleolus organizer regions of the canine karyotype, Cytogenet Cell Genet, 35, 293-4.

20. Jelesijević $T$, 2001, Odnos pathohistoloških karakteristika tumora mlečne žlezde kuja i broja organizatora nukleolusa, Magistarska teza, Beograd.

21. Juntes P, Pogačnik M, 2000, Morphometric analysis of AgNORs in tubular and papillary parts of canine mammary gland tumors, Anal Quant Cytol Histol, 22, 185-92.

22. Kiupel M, Bostock $D E$, Bergmann RL, 1998, A semiquantitative method for the evaluation of AgNORs in canine malignant lymphomas, Eur J Vet Pathol, 4, 67-71. 
23. Kiupel M, Teske E, Bostock DE, 1999, Prognostic factors for treated canine malignant lymphoma, Vet Pathol, 36, 292-300.

24. Kravis LD, Vail MD, Kisseberth CW, Oglivie KG, Volk ML, 1996, Frequency of argyrophilic nucleolar organizer regions in fine-needle aspirates and biopsy specimens from mast cell tumors in dogs, JAVMA, 209, 1418-20.

25. Magaš V, 2002, Procena maligniteta tumora mlečne žlezde kuja, Magistarska teza, Beograd.

26. Misdorp W, Cotchin E, Hampe JF, Jabara AG, Sandersleben J, 1971, Canine malignant mammary tumors. I. Sarcomas, Vet Pathol, 8, 99-117.

27. Misdorp W, Else RW, Hellmen E, Lipscomb TP, 1999, Histological classification of mammary tumors of the dog and the cat. WHO International Histological Classification of Tumors of Domestic Animals, Second Series Volume VII. Published by the Armed Forces Institute of Pathology in cooperation with the American Registry of Pathology and the WHO Collaboration Center for Worldwide Reference on Comparative Oncology, Washington, D.C.

28. Moulton JE, Taylor DON, Dorn CR, Andersen AC, 1970, Canine mammary tumors, Path Vet, 7, 289320.

29. Moulton JE, Rosenblat LS and Goldman M, 1986, Mammary tumors in a colony of beagle dogs, Vet Pathol, 23, 731-49.

30. Moulton JE, 1990, Tumors in Domestic Animals. Third edition, revised and expanded, University of California press.

31. Rüschoff J, Fauser G, Knüchel R, Hofstädter F, 1994, AgNOR quantification with special reference to staining patterns, Zentralbl Pathol, 140, 23-30.

32. Shibasaki Y, Polsen BS, Johanesen B, Ronne M, 1990, Banding studies in Canis familiaris. II. Nucleolar organizer regions and NOR association, In Vivo, 4, 243-6.

\title{
KVANTITATIVNA I KVALITATIVNA ANALIZA AgNOR KOD BENIGNIH I MALIGNIH TUMORA MLEČNE ŽLEZDE KUJA
}

\author{
JELESIJEVIĆ T, JOVANOVIĆ M, KNEŽEVIĆ MILIJANA i ALEKSIĆ-KOVAČEVIĆ SANJA
}

\section{SADRŽAJ}

U ovoj retrospektivnoj studiji izvršena je kvalitativna i kvantitativna analiza arigrofilnih organizatora nukleolusa (AgNORs), 54 maligna i 18 benignih tumora mlečne žlezde pasa. Uočene su statistički značajne razlike u prosečnom broju AgNORs po ćeliji između benignih i malignih tumora $(p<0.01)$. Nisu dokazane statistički značajne razlike u prosečnom broju AgNORs po ćeliji između kompleksnih karcinoma, prostih karcinoma i karcinoma u mešovitom tumoru $(p>0.05)$. Zapaženo je šest različitih tipova distribucije AgNORs. Tipovi I, II, III i samo u dva slučaja tip IV su uočeni kod benignih tumora, dok su kod malignih tumora uočeno svih šest tipova. Dominantni tipovi kod malignih tumora su III, IV, V and VI. Ćelije tipa II, III i IV dominiraju kod tumora kji imaju prosečno 5.5-7 AgNORs po ćeliji, dok tipovi V i VI su dominantni kod tumora koji imaju prosečno više od 7 AgNORs po ćeliji. 